\title{
ENERGY EFFICIENCY OF AGRICULTURAL TRACTORS EQUIPPED WITH CONTINUOUSLY VARIABLE AND FULL POWERSHIFT TRANSMISSION SYSTEMS
}

\author{
Lauro Strapasson Neto ${ }^{1}$, Gabriel G. Zimmermann ${ }^{1 *}$, Samir P. Jasper ${ }^{1}$, \\ Daniel Savi $^{1}$, Luiz R. Sobenko ${ }^{2}$ \\ ${ }^{1 *}$ Corresponding author. Universidade Federal do Paraná/ Curitiba - PR, Brazil. \\ E-mail: gabrielganancini@gmail.com | ORCID ID: https://orcid.org/0000-0002-9709-4458
}

\section{KEYWORDS}

fuel consumption, operational velocity, performance, power.

\begin{abstract}
The efficiency of agricultural tractor transmission has been improved over the years, with new concepts such as Continuously Variable Transmission (CVT) and Full Powershift (FPS) evolving in advanced technologies. Both options seek to offer the farmer greater operational results with lower energy expenditure, necessitating studies to assess the effectiveness of these technologies and define the best choice for each purpose. The objective of this work was to evaluate the energy efficiency of two tractors equipped with CVT and FPS transmissions. For this, a strip experiment was conducted in a randomized block design, that analyzed, in addition to CVT and FPS transmissions, target velocities of 4, 6, 8 and $10 \mathrm{~km} \mathrm{~h}^{-1}$. Operational energy performance parameters were evaluated, such as slippage index, engine rotation, operational velocity, fuel consumption, power available and efficiency on the drawbar, turbo pressure and temperatures of air intake and exhaust gas. Based on the results obtained, the tractor with FPS transmission was more energy efficient in most of the analyzed parameters, requiring $16.31 \%$ less in hourly fuel consumption, and providing $16.29 \%$ more in the traction bar yield, however, with lower operational velocity compared to the tractor with CVT transmission.
\end{abstract}

\section{INTRODUCTION}

In essence, agricultural tractors are designed to efficiently convert energy from fossil fuels into traction force, while towing and mounting implements in the most varied environments (Xia et al., 2020). In addition to promoting the proper burning of fuels, it is essential that the tractor power train transmits the energy to the driving wheels, an action for which the transmission is responsible, through a set of combinations that allow a variation of torque and speed (Park et al., 2016).

Currently, different types of transmission are offered in the global agricultural machinery market, especially tractor models with Continuously Variable Transmissions (CVT) and automated Full Powershift (FPS), which, according to Mattetti et al. (2019), also stand out in terms of efficiency factors. CVT transmission works through pumps and hydraulic components driven by the motor energy, in which gears combine hydraulic and mechanical force, allowing the infinitely variable activation of ratio ranges, resulting in high operational capacity and transmission efficiency (Rotella \& Cammalleri, 2018). Automatic FPS transmission operates by adjusting the gears and rotation of the engine through the electronic manager, with the gear coupling carried out by an electro-hydraulic system, which limits the number of gears (Li et al., 2019).

The energy efficiency achieved by agricultural tractors is directly related to the efficiency parameters of the engines and how this energy is transmitted during traction, with an emphasis on the transmission architecture. Thus, a knowledge of transmission efficiency allows to estimate the losses of energy supplied through combustion during the execution of agricultural operations (Bietresato et al., 2012; Damanauskas \& Janulevičius, 2015).

\footnotetext{
${ }^{1}$ Universidade Federal do Paraná/ Curitiba - PR, Brazil.

${ }^{2}$ Valley Irrigation - Valmont Industries/ Uberaba - MG, Brazil.

Area Editor: Murilo Aparecido Voltarelli

Received in: 3-29-2021

Accepted in: 1-10-2022
} 
The performance and quality of the agricultural operation are influenced by the operational velocity, which is related to the efficiency and the amount of power provided by the power train (Jasper et al., 2016). Moreover, the agricultural tractor must use the maximum engine power with the minimum fuel consumption, which increases proportionally with the increase in traction force and operational velocity (Damanauskas et al., 2019; Simikic et al., 2014).

Farias et al. (2017) evaluated the fuel consumption efficiency of a tractor equipped with CVT transmission, at different travel velocities and partial loads on the tractor's drawbar, and found that, in general, the specific fuel consumption decreased as partial loads and velocities were increased. Molari \& Sedoni (2008), when evaluating the energy performance of a tractor equipped with FPS transmission in different operational conditions, found high energy losses in high gears, passive resistance and friction in the transmission together with the power absorbed by the hydraulic circuit in the neutral position.

Based on this, in this paper we evaluate the energy efficiency of two tractors equipped with CVT and FPS transmissions, subjected to traction effort at different target velocities.

\section{MATERIAL AND METHODS}

\section{Experimental design}

The research was conducted on a concrete surface, in an experimental area in Pinhais, PR, Brazil, according to ASAE (2011a). The banded experiment, conducted in a randomized block design, consisted of two tractors with CVT and FPS transmissions (T), allocated to plots, and the target velocities $\left(\mathrm{v}_{\mathrm{T}}\right)$ in the subplots $\left(4,6,8\right.$ and $\left.10 \mathrm{~km} \mathrm{~h}^{-1}\right)$, resulting in eight treatments. For each treatment, five repetitions were performed, totalling 40 experimental units, in bands of 50-m length each.

The tractors evaluated in this research were the Case IH® models Magnum 380 and 340, with CVT and FPS transmissions, respectively; their technical specifications are shown in TABLE 1. The tractor with FPS transmission was equipped with automatic productivity management, which was kept activated during the tests, automatically selecting the gear ratio and engine rotation according to the transmission's load, the hydraulic system and the power take-off, maintaining the constant pressure of the clutch (Strapasson et al., 2020). Moreover, $40 \%$ of hydraulic ballast was added to all the tyres of both tractors, resulting in the static mass also shown in TABLE 1.

TABLE 1. Technical specifications of the tractors.

\begin{tabular}{|c|c|c|c|c|}
\hline Tractor & \multicolumn{2}{|l|}{ Case IH Magnum 380} & \multicolumn{2}{|l|}{ Case IH Magnum 340} \\
\hline Transmission & \multicolumn{2}{|l|}{ CVT } & \multicolumn{2}{|l|}{ FPS $(18 x 4)$} \\
\hline Nominal power $(\mathrm{kW} / \mathrm{cv})^{*}$ & \multicolumn{2}{|l|}{$283 / 380$} & \multicolumn{2}{|l|}{$250 / 340$} \\
\hline Traction type & \multicolumn{2}{|l|}{$4 \times 2 \mathrm{AFWD}^{* *}$} & \multicolumn{2}{|l|}{$4 \times 2 \mathrm{AFWD}^{* *}$} \\
\hline Anticipation index $(\%)$ & \multicolumn{2}{|l|}{1.68} & \multicolumn{2}{|l|}{1.60} \\
\hline Total static mass (kg) & \multicolumn{2}{|l|}{$21,171.34$} & \multicolumn{2}{|l|}{$18,631.23$} \\
\hline $\begin{array}{l}\text { Power-mass ratio } \\
\left(\mathrm{N} \mathrm{kW}^{-1} / \mathrm{N} \mathrm{cv}^{-1}\right)\end{array}$ & \multicolumn{2}{|l|}{733.59 / 546.32} & \multicolumn{2}{|l|}{$730.85 / 537.39$} \\
\hline & Front-axle & Rear-axle & Front-axle & Rear-axle \\
\hline \multirow[t]{2}{*}{ Static mass distribution (\%) } & 40 & 60 & 42 & 58 \\
\hline & Front tyres & Rear tyres & Front tyres & Rear tyres \\
\hline Tyre type & Goodyear 480/70R34 & Goodyear 710/70R42 & Goodyear 480/70R34 & Goodyear 710/70R42 \\
\hline Tyre pressure (kPa/psi) & $\begin{array}{l}96.50 / 14(\mathrm{I})^{* * *} \\
82.74 / 12(\mathrm{E})^{* * * *}\end{array}$ & $\begin{array}{l}68.95 / 10(\mathrm{I})^{* * *} \\
55.20 / 8(\mathrm{E})^{* * * *}\end{array}$ & $\begin{array}{l}96.50 / 14(\mathrm{I})^{* * *} \\
82.74 / 12(\mathrm{E})^{* * * *}\end{array}$ & $\begin{array}{l}68.95 / 10(\mathrm{I})^{* * *} \\
55.20 / 8(\mathrm{E})^{* * * *}\end{array}$ \\
\hline
\end{tabular}

*ISO TR14396; **AFWD - auxiliary front-wheel drive; ***I - internal wheelset; ****E - external wheelset.

The experiment was conducted using the train method, that is, the evaluated tractors pulled a third Case IH Steiger model tractor, which acted as a brake. Braking was performed by a pre-established gear, providing $103 \mathrm{kN}$ as traction force, selected based on the ASAE (2011b) standard, which resulted in an available power of $198.5 \mathrm{~kW}$
$(270 \mathrm{cv})$ in the drawbar. During the experiment, both tractors had AFWD activated and the fuel tank was also full.

\section{Evaluated parameters}

The tractors were fitted with sensors described below (FIGURE 1), connected to a data acquisition system, with a printed circuit board as described in Jasper et al. (2016). 


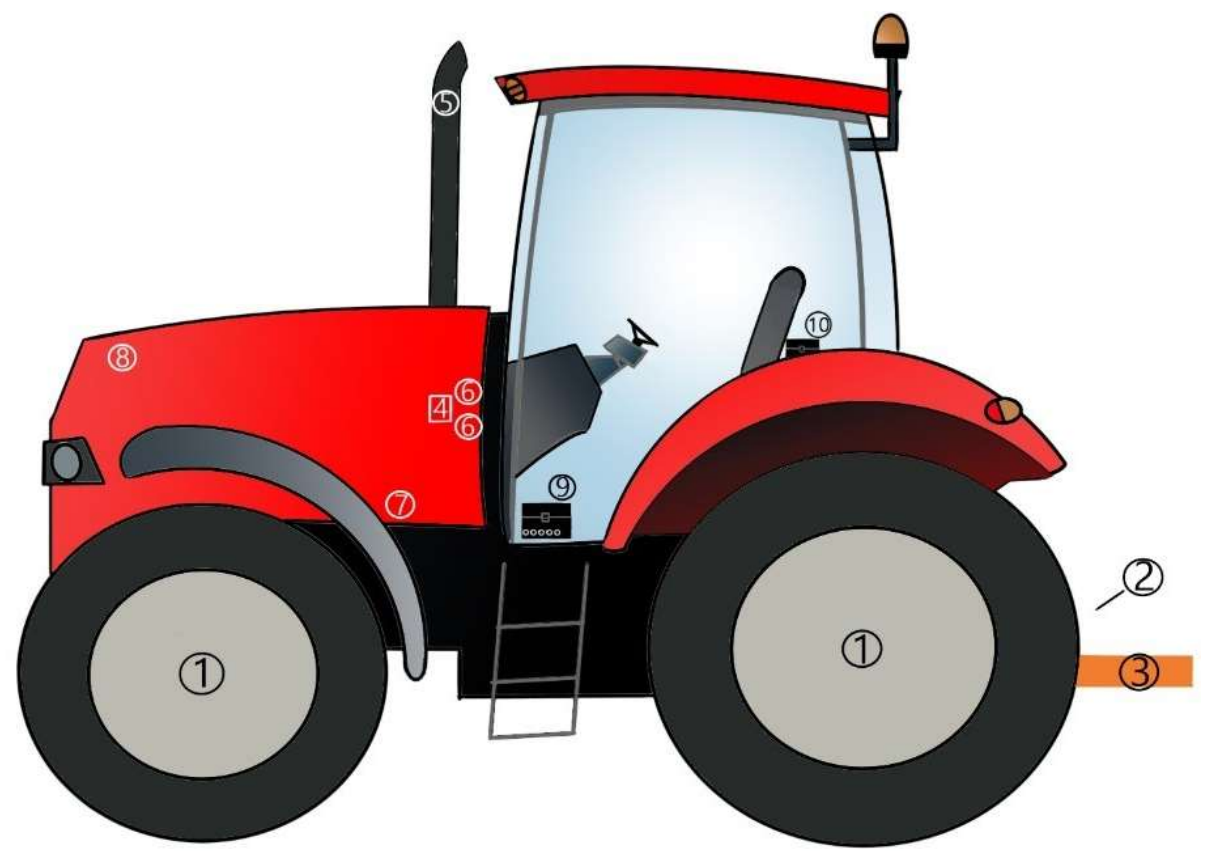

FIGURE 1. The following sensors are arranged in the following order: Encoders on the four wheelset (1), Encoder on the power take-off (2), Load cell (3), Inlet and outlet flowmeters (4), Exhaust temperature sensor (5), Sensors Temperature Sensor (6), Engine Oil Temperature Sensor (7), Cooling Air Temperature Sensor (8), Temperature Data Acquisition Box (9) and Central Data Acquisition Box (10).

The following operational energy performance parameters were evaluated: slippage index $\left(\mathrm{S}_{\mathrm{I}}\right)$; engine rotation $\left(\mathrm{E}_{\mathrm{R}}\right)$; hourly $\left(\mathrm{FC}_{\mathrm{H}}\right)$ and specific $\left(\mathrm{FC}_{\mathrm{S}}\right)$ fuel consumptions, and engine thermal efficiency $\left(\mathrm{ET}_{\eta}\right)$. The determination of these parameters are fully described in Strapasson et al. (2020). The operational velocity $\left(\mathrm{v}_{\mathrm{O}}\right)$ was determined as a function of the number of pulses emitted by 740030A radar (Vansco Electronics LP Inc., Canada).

The turbo pressure (TP), force $\left(\mathrm{DB}_{\mathrm{F}}\right)$, power available $\left(\mathrm{DB}_{\mathrm{P}}\right)$ and efficiency $\left(\mathrm{DB}_{\eta}\right)$ on the drawbar, and air intake $\left(\mathrm{I}_{\mathrm{T}}\right)$ and exhaust gas $\left(\mathrm{E}_{\mathrm{T}}\right)$ temperatures, were determined according to Oiole et al. (2019). Furthermore, TP was measured using a MPX 5700DP piezoresistive pressure transducer model (Motorola Inc.) to assess the pressure at the tractor engine intake manifold during the tests; and $\mathrm{I}_{\mathrm{T}}$ and $\mathrm{E}_{\mathrm{T}}$ were measured during the test using type- $\mathrm{K}$ thermocouples placed at the air filter inlet, and exhaust, respectively.

The data collected from the described parameters were assessed by normality (SW - Shapiro-Wilk) and homogeneity of variance (BF - Brown-Forsythe). Given these premises, they were subjected to analysis of variance (ANOVA) to verify the effects of factors $\left(\mathrm{T}\right.$ and $\mathrm{v}_{\mathrm{T}}$ ) and their interaction, through the statistical software SigmaPlot 12 (Systat Software Inc., CA, USA). When the F-test presented a significant probability value $(\mathrm{P}<0.05)$, the averages were compared using the Tukey test $(\mathrm{P}<0.05)$ for qualitative factors $(\mathrm{T})$. The regression test was applied for quantitative factors $\left(\mathrm{v}_{\mathrm{T}}\right.$ and interaction), with models selected by the criterion with the highest determination coefficient $\left(R^{2}\right)$ and significance $(p<0.05)$ of the equation parameters. Furthermore, to facilitate the presentation and discussion of the results obtained, the data were separated into two datasets.

\section{RESULTS AND DISCUSSION}

TABLE 2 shows the synthesis results for the analyses of the first set of operational energy performance parameters, with no need to transform the means, denoting the normality (SW) and homogeneity of the variance residues $(\mathrm{BW})$, except for the $\mathrm{FC}_{\mathrm{H}}$ and $\mathrm{v}_{\mathrm{O}}$ parameters, which showed heterogeneous behavior. Moreover, the coefficient of variation $\left(\mathrm{C}_{\mathrm{V}}\right)$ in all parameters was categorized as "stable", except for $\mathrm{S}_{\mathrm{I}}$, which was classified as "average dispersion" (Ferreira, 2018). 
TABLE 2. Synthesis of the analysis of variance and the test of means for the evaluated operational energy performance parameters (Set I).

\begin{tabular}{|c|c|c|c|c|c|c|c|}
\hline \multirow{2}{*}{\multicolumn{2}{|c|}{ Analysis }} & \multicolumn{6}{|c|}{ Parameters } \\
\hline & & $\begin{array}{c}\mathrm{S}_{\mathrm{I}} \\
(\%)\end{array}$ & $\begin{array}{c}\mathrm{E}_{\mathrm{R}} \\
(\mathrm{rpm})\end{array}$ & $\begin{array}{c}\mathrm{FC}_{\mathrm{H}} \\
\left(\mathrm{L} \mathrm{h}^{-1}\right)\end{array}$ & $\begin{array}{l}\mathrm{DB}_{\mathrm{F}} \\
(\mathrm{kN})\end{array}$ & $\begin{array}{c}\mathrm{v}_{\mathrm{O}} \\
\left(\mathrm{km} \mathrm{h}^{-1}\right)\end{array}$ & $\begin{array}{c}\mathrm{DB}_{\mathrm{P}} \\
(\mathrm{kW})\end{array}$ \\
\hline & SW & 0.650 & 0.277 & 0.726 & 0.138 & 0.319 & 0.805 \\
\hline & $\mathrm{BF}$ & 0.917 & 0.735 & 0.042 & 0.892 & 0.033 & 0.500 \\
\hline \multirow{3}{*}{-test } & $\mathrm{T}$ & $52.42^{* *}$ & $7,703.01^{* *}$ & $2,143.81^{* *}$ & $9.86^{*}$ & $30.89^{* *}$ & $119.67^{* *}$ \\
\hline & $\mathrm{v}_{\mathrm{T}}$ & $15.99^{* *}$ & $3,715.75^{* *}$ & $303.89^{* *}$ & $1.07^{\mathrm{NS}}$ & $5,095.75^{* *}$ & $903.41^{* *}$ \\
\hline & $\mathrm{T} \times \mathrm{v}_{\mathrm{T}}$ & $0.56^{\mathrm{NS}}$ & $1,255.78^{* *}$ & $29.28^{* *}$ & $7.06^{* *}$ & $5.13^{*}$ & $9.07^{* *}$ \\
\hline \multirow{3}{*}{$\mathrm{v}(\%)$} & $\mathrm{T}$ & 13.06 & 0.45 & 1.21 & 2.84 & 1.81 & 1.94 \\
\hline & $\mathrm{v}_{\mathrm{T}}$ & 15.32 & 0.40 & 4.76 & 3.95 & 1.49 & 3.44 \\
\hline & $\mathrm{T} \times \mathrm{v}_{\mathrm{T}}$ & 16.66 & 0.37 & 5.90 & 2.86 & 1.69 & 2.52 \\
\hline \multirow{2}{*}{ Iean test } & $380 \mathrm{CVT}$ & $2.38 \mathrm{~b}$ & $1,548 \mathrm{~b}$ & $46.89 \mathrm{a}$ & $68.03 \mathrm{~b}$ & $7.13 \mathrm{a}$ & $129.62 \mathrm{~b}$ \\
\hline & 340 FPS & $3.22 \mathrm{a}$ & $1,756 \mathrm{a}$ & $39.24 \mathrm{~b}$ & $69.97 \mathrm{a}$ & $6.61 \mathrm{~b}$ & $138.60 \mathrm{a}$ \\
\hline
\end{tabular}

Values with different letters in a column are significantly different $(\mathrm{P}<0.05)$. F-test: NS - not significant; * $-\mathrm{P}<0.05 ; * *-\mathrm{P}<0.01$. ShapiroWilk normality test: $\mathrm{SW} \leq 0.05$ - abnormal data; $\mathrm{SW}>0.05$ - data normality. Brown-Forsythe homogeneity test: $\mathrm{BW} \leq 0.05-$ heterogeneous variances; $\mathrm{BW}>0.05$ - homogeneous variances. $\mathrm{C}_{\mathrm{V}}$ - coefficient of variation; $\mathrm{S}_{\mathrm{I}}-$ slippage index; $\mathrm{E}_{\mathrm{R}}-$ engine rotation; $\mathrm{FC}_{\mathrm{H}}-$ hourly fuel consumption; $\mathrm{DB}_{\mathrm{F}}$ - force on the drawbar; $\mathrm{v}_{\mathrm{O}}$ - operational velocity; $\mathrm{DB}_{\mathrm{P}}$ - power on the drawbar; $\mathrm{T}-$ transmission factor; $\mathrm{v}_{\mathrm{T}}-$ target velocity factor; $380 \mathrm{CVT}$ - tractor with CVT transmission; 340 FPS - tractor with FPS transmission.

The results obtained for both tractors in the slip were below the range recommended by ASAE (2011a), which recommends 4 to $8 \%$ when operated on a concrete surface. The 340 FPS slipped $0.84 \%$ more than the $380 \mathrm{CVT}$, therefore requiring greater engine rotation $(13.4 \%)$ (TABLE 2). This can be explained by the fact that the $S_{I}$ is delimited in an ideal range, with minimum values representing overload in the power train and maximum values indicating energy expenditure generated by the greater surface-tyre interaction (Battiato \& Diserens, 2017).

The tractor with CVT transmission consumed $16.3 \%$ more fuel per hour compared to the 340 FPS transmission (TABLE 2). The operation of the CVT system occurs through the hydraulic force provided by an auxiliary pump, demanding greater power consumption from the engine, which results in a greater energy expenditure to reach the target velocity, even at lower engine rotation $(\mathrm{Qu}$ et al., 2019). Furthermore, the highest consumption, even in smaller $E_{R}$, was provided by the electronic management of the CVT transmission in relation to FPS, which does not

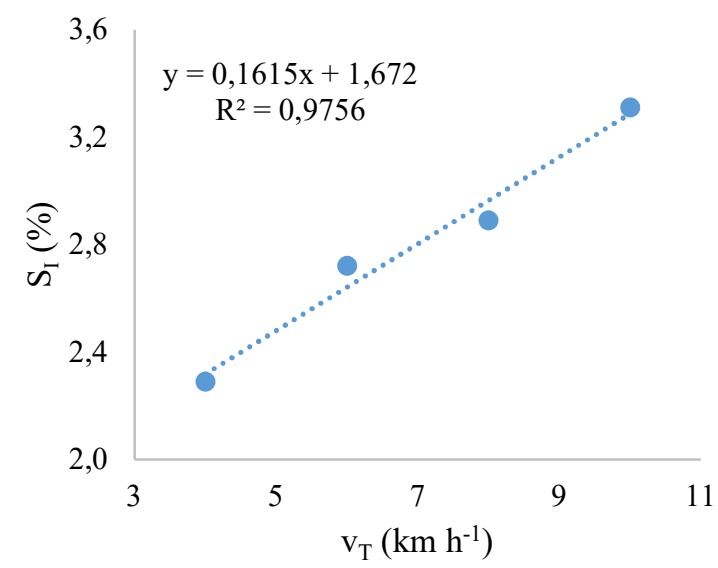

(a) take into account only the $\mathrm{E}_{\mathrm{R}}$, but also the necessary load for the activation of the aforementioned hydraulic pump.

In TABLE 2, the force exerted on the drawbar was slightly higher for the 340 FPS $(2.9 \%)$, which may have been provided by the higher $\mathrm{S}_{\mathrm{I}}$, indicating an increase in the tyre-surface interaction, providing notable growth in the traction on the drawbar (Battiato \& Diserens, 2017). Also, in TABLE 2, the 380 CVT expressed a $7.9 \%$ higher $\mathrm{v}_{\mathrm{O}}$, corroborating Bietresato et al. (2012), who also obtained a higher operational speed with a tractor equipped with this type of transmission in relation to a tractor with automatic transmission. And finally, the power available on the drawbar was $6.9 \%$ higher for the 340 FPS tractor, a result that can be explained by the higher $\mathrm{DB}_{\mathrm{F}}$ compared to the 380 CVT.

Analyzing the effect of the target velocities on the parameters evaluated so far, linear behaviours were observed for $\mathrm{S}_{\mathrm{I}}, \mathrm{FC}_{\mathrm{H}}, \mathrm{v}_{\mathrm{O}}$ and $\mathrm{DB}_{\mathrm{P}}$, and quadratic for $\mathrm{E}_{\mathrm{R}}$, with $\mathrm{R}^{2}>0.97$ in all cases (FIGURE 2 ).

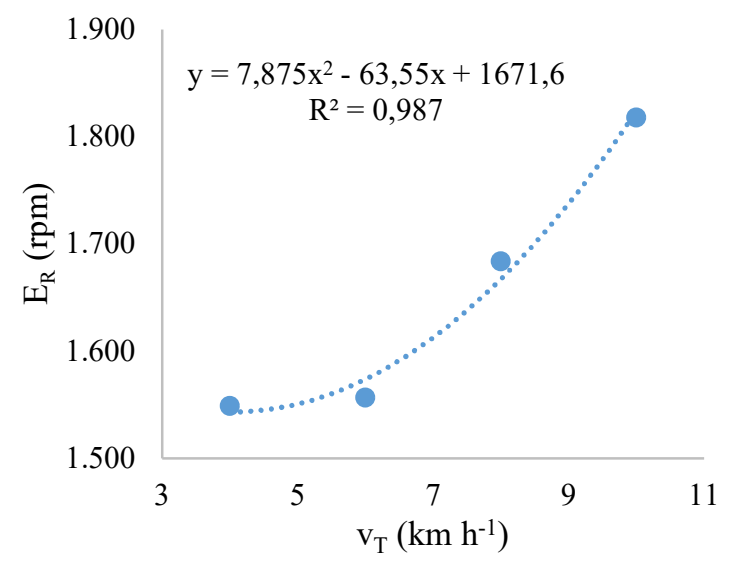

(b) 


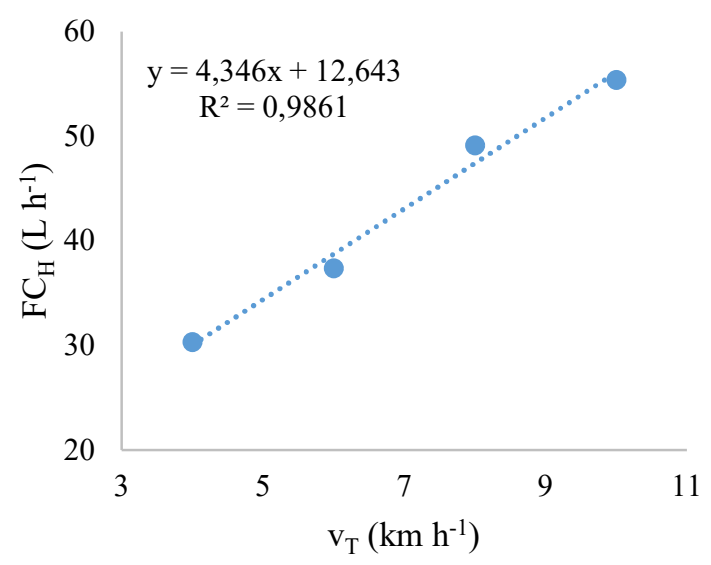

(c)

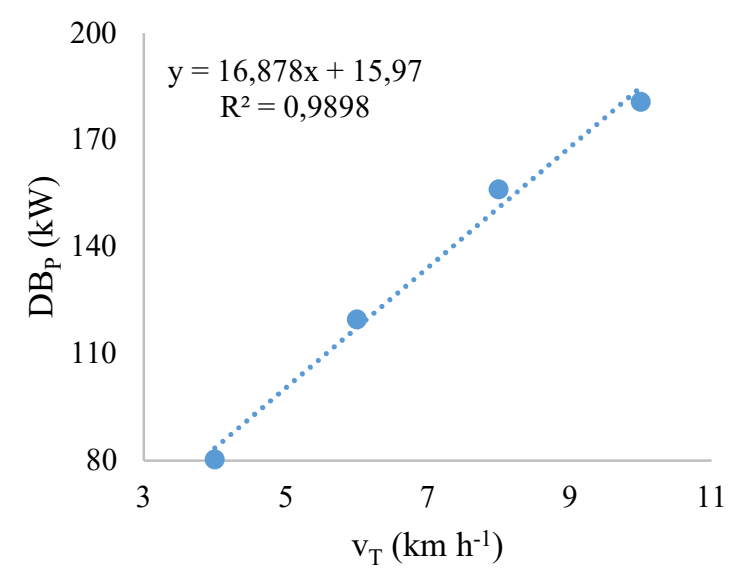

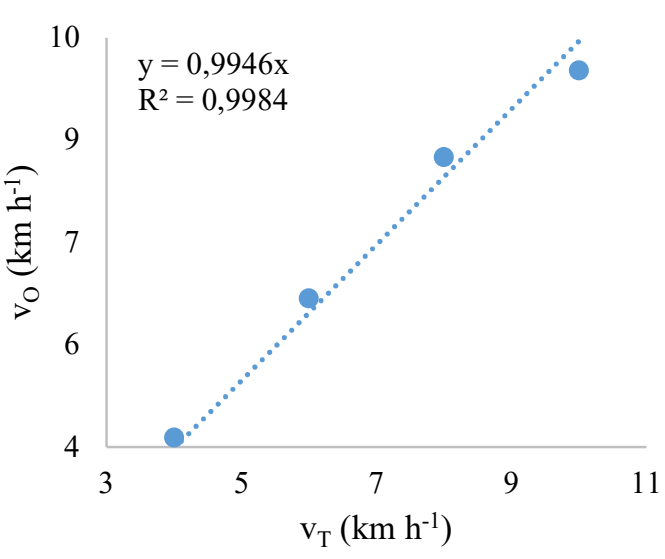

(d)

(e)

FIGURE 2. Regression analysis for the isolated target velocity $\left(\mathrm{v}_{\mathrm{T}}\right)$ factor in the parameters: (a) slippage index $\left(\mathrm{S}_{\mathrm{I}}\right)$; (b) engine rotation $\left(\mathrm{E}_{\mathrm{R}}\right)$; (c) hourly fuel consumption $\left(\mathrm{FC}_{\mathrm{H}}\right)$; (d) operational velocity $\left(\mathrm{v}_{\mathrm{O}}\right)$; and, (e) power on the drawbar $\left(\mathrm{DB}_{\mathrm{P}}\right)$.

According to the generated equation in FIGURE 2a, an increase of $0.16 \%$ in slip is observed with an increase of $1 \mathrm{~km} \mathrm{~h}^{-1}$, added to the $1.67 \%$ necessary for the system to minimize overload on the transmission components. It can be explained by the slippage index being influenced by the selected ballast and target velocity (Monteiro et al., 2011). Regarding the equation for the engine rotation in FIGURE $2 \mathrm{~b}$, it is observed that the lowest rotation of $1,544 \mathrm{rpm}$ occurred at the target speed of $4 \mathrm{~km} \mathrm{~h}^{-1}$, considering that the performance of the automatic productivity management in the transmission, in order to reach the target velocity, influenced the engine rotation (Strapasson et al., 2020). For hourly fuel consumption, there was an increasing trend of $4.34 \mathrm{~L} \mathrm{~h}^{-1}$ every $1 \mathrm{~km} \mathrm{~h}^{-1}$, added to the $12.64 \mathrm{~L} \mathrm{~h}^{-1}$ required for the maintenance of the power train components (FIGURE 2c). This increase in $\mathrm{FH}_{\mathrm{C}}$ is due to the selection of high gears to result in a higher effective speed, and, consequently, to increase fuel consumption (Martins et al., 2018).
By the equation presented in FIGURE $2 \mathrm{~d}$ for the operational velocity, it is possible to reach $99.46 \%$ of the desired velocity due to the slippage of the driving wheels and the occurrence of alternations in the loading moments on the engine. This situation occurs because the traction component is related to the torque transmission performance of the wheel to the drawbar, in addition to $v_{O}$ being given by the wheels spinning, corroborating with Vantsevich (2007). For the power in the drawbar, the equation obtained allows an increase of $16.87 \mathrm{~kW}$ to be observed, added to the $15.97 \mathrm{~kW}$ results of the product of the traction force by the displacement velocity (FIGURE 2e), which can be explained by the greater applied target velocity providing an increase in the performance of power in the drawbar; a similar result was also reported by Gabriel Filho et al. (2010).

Due to the significant interactions observed between $\mathrm{v}_{\mathrm{T}}$ and types of transmission shown in TABLE 2, it was possible to generate equations capable of representing them (FIGURE 3). 


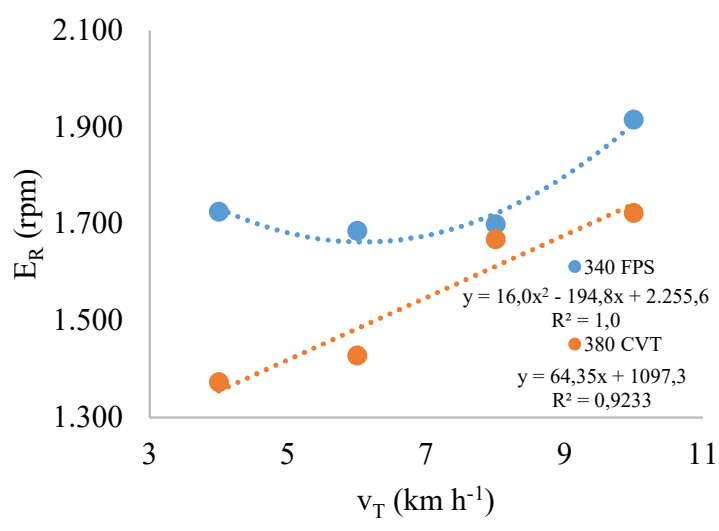

(a)

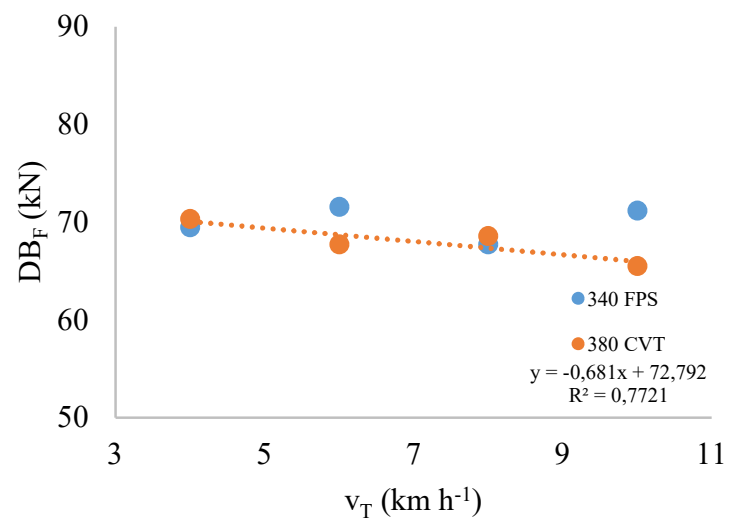

(c)

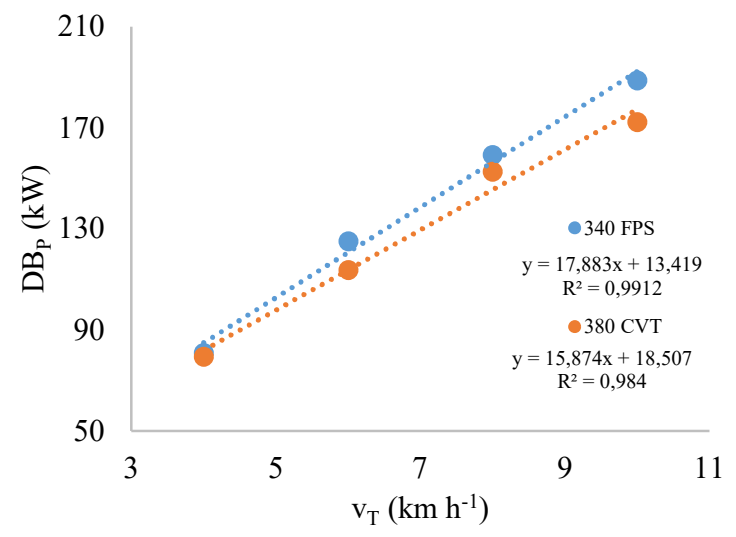

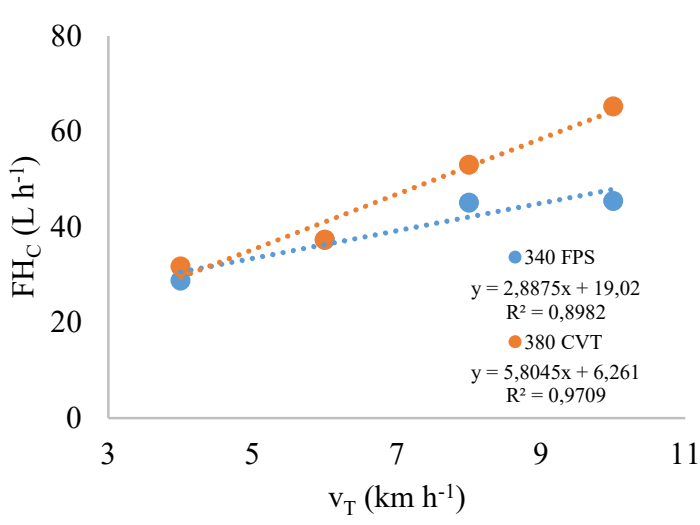

(b)

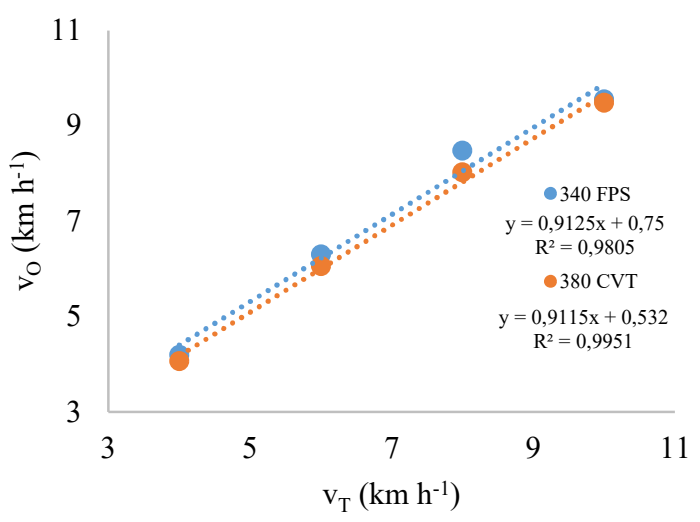

(d)

(e)

FIGURE 3. Regression analysis of the interaction transmissions (340 FPS and $380 \mathrm{CVT}$ ) and target velocity ( $\mathrm{v}_{\mathrm{T}}$ ) in the parameters: (a) engine rotation $\left(\mathrm{E}_{\mathrm{R}}\right)$; (b) hourly fuel consumption $\left(\mathrm{FC}_{\mathrm{H}}\right)$; (c) force on the drawbar $\left(\mathrm{DB}_{\mathrm{F}}\right)$; (d) operational velocity $\left(\mathrm{v}_{\mathrm{O}}\right)$; and $(\mathrm{e})$ power on the drawbar $\left(\mathrm{DB}_{\mathrm{P}}\right)$.

For the engine rotation, it is noted that the $380 \mathrm{CVT}$ and 340 FPS presented linear and quadratic equations with the increase in $\mathrm{v}_{\mathrm{T}}$, respectively (FIGURE 3a). It is also observed that for the 340 FPS it reaches the minimum $E_{R}$ (1,662 RPM), the $\mathrm{v}_{\mathrm{T}}$ will be $6 \mathrm{~km} \mathrm{~h}^{-1}$, in addition to presenting an $E_{R}$ higher than that of the $380 \mathrm{CVT}$ in all evaluated $\mathrm{v}_{\mathrm{T}}$, corroborating with Piros \& Farkas (2012).

Hourly fuel consumption was similar at the lowest speeds for both transmissions, however, for the two highest $\mathrm{v}_{\mathrm{T}}$, the 340 FPS demanded an average of $22.60 \%(-13.83 \mathrm{~L}$ $\mathrm{h}^{-1}$ ) less fuel than the $380 \mathrm{CVT}$, demonstrating its energy advantage (FIGURE 3b). This result corroborates the postulate by Mayet et al. (2019) that conventional CVT technology is not yet competitive due to its relatively lower efficiency compared to other transmission models. For the force on the drawbar, there was no trend for the 340 FPS that can be explained mathematically (FIGURE 3c). On the other hand, for the $380 \mathrm{CVT}$, there was a decreasing behaviour for the $\mathrm{DB}_{\mathrm{F}}$ as a function of $\mathrm{v}_{\mathrm{T}}$, corroborating with Lopes et al. (2010) when describing that the $\mathrm{DB}_{\mathrm{F}}$ is related to the traction force and $v_{O}$, since at lower $v_{O}$ there is a greater traction force.

The operational velocity on both tractors showed similar behaviour, with a slight average advantage of $3.27 \%$ for the 340 FPS compared to the 380 CVT (FIGURE 3d). In addition, the interaction between $\mathrm{DB}_{\mathrm{P}}$ and target speeds also demonstrates an advantage for the 340 FPS tractor, which was, on average, $6.44 \%$ higher for all $\mathrm{v}_{\mathrm{T}}$, with a greater distance from the $380 \mathrm{CVT}$ at higher velocities (FIGURE 3e). 
TABLE 3 shows the synthesis results for the analyses of the second set of operational energy performance parameters, which also did not show the need to transform the means. With the exception of the $\mathrm{E}_{\mathrm{T}}$ parameter, the others showed normal variance residues (SW). For homogeneity of the variance residues (BF), the parameters $\mathrm{PT}$ and $\mathrm{I}_{\mathrm{T}}$ showed heterogeneous behaviour. Moreover, all $\mathrm{C}_{\mathrm{V}}$ are categorized as "stable" (Ferreira, 2018).

TABLE 3. Synthesis of the analysis of variance and the test of means for the evaluated operational energy performance parameters (Set II).

\begin{tabular}{|c|c|c|c|c|c|c|c|}
\hline \multirow{2}{*}{\multicolumn{2}{|c|}{ Analysis }} & \multicolumn{6}{|c|}{ Parameters } \\
\hline & & $\begin{array}{l}\mathrm{DB}_{\eta} \\
(\%)\end{array}$ & $\begin{array}{c}\mathrm{FC}_{\mathrm{S}} \\
\left(\mathrm{g} \mathrm{kW} \mathrm{h}^{-1}\right)\end{array}$ & $\begin{array}{l}\mathrm{ET}_{\eta} \\
(\%)\end{array}$ & $\begin{array}{c}\mathrm{TP} \\
(\mathrm{kPa})\end{array}$ & $\begin{array}{c}\mathrm{I}_{\mathrm{T}} \\
\left({ }^{\circ} \mathrm{C}\right)\end{array}$ & $\begin{array}{c}E_{\mathrm{T}} \\
\left({ }^{\circ} \mathrm{C}\right)\end{array}$ \\
\hline & SW & 0.199 & 0.520 & 0.534 & 0.191 & 0.985 & 0.062 \\
\hline & BF & 0.523 & 0.521 & 0.259 & 0.049 & 0.026 & 0.929 \\
\hline \multirow{3}{*}{-test } & $\mathrm{T}$ & $850.94^{* *}$ & $993.94^{* *}$ & $740.63^{* *}$ & $0.307^{\mathrm{NS}}$ & $1,540.50^{* *}$ & $259.01^{* *}$ \\
\hline & $\mathrm{v}_{\mathrm{T}}$ & $898.76^{* *}$ & $34.26^{* *}$ & $33.72^{* *}$ & $295.02^{* *}$ & $572.22^{* *}$ & $721.96^{* *}$ \\
\hline & $\mathrm{T} \times \mathrm{v}_{\mathrm{T}}$ & $21.08^{* *}$ & $18.62^{* *}$ & $33.33^{* *}$ & $26.07^{* *}$ & $870.88^{* *}$ & $77.67^{* *}$ \\
\hline \multirow{3}{*}{$v(\%)$} & $\mathrm{T}$ & 1.92 & 2.07 & 2.57 & 2.80 & 1.93 & 5.72 \\
\hline & $\mathrm{v}_{\mathrm{T}}$ & 3.47 & 6.05 & 6.19 & 4.23 & 0.90 & 1.51 \\
\hline & $\mathrm{T} \times \mathrm{v}_{\mathrm{T}}$ & 2.76 & 5.38 & 5.18 & 2.24 & 1.02 & 4.31 \\
\hline \multirow{2}{*}{ Iean test } & $380 \mathrm{CVT}$ & $46.50 \mathrm{~B}$ & $310 \mathrm{~A}$ & $27.73 \mathrm{~B}$ & $83.81 \mathrm{~A}$ & $27.04 \mathrm{~B}$ & $183.52 \mathrm{~B}$ \\
\hline & 340 FPS & $55.55 \mathrm{~A}$ & $252 \mathrm{~B}$ & $34.62 \mathrm{~A}$ & $82.83 \mathrm{~A}$ & $34.30 \mathrm{~A}$ & $246.04 \mathrm{~A}$ \\
\hline
\end{tabular}

Values with different letters in a column are significantly different $(\mathrm{P}<0.05)$. F-test: NS - not significant; ${ }^{*}-\mathrm{P}<0.05 ;{ }^{* *}-\mathrm{P}<0.01$. ShapiroWilk normality test: SW $\leq 0.05$ - abnormal data; SW $>0.05$ - data normality. Brown-Forsythe homogeneity test: BW $\leq 0.05-$ heterogeneous variances; $\mathrm{BW}>0.05$ - homogeneous variances. $\mathrm{C}_{\mathrm{V}}$ - coefficient of variation; $\mathrm{DB}_{\eta}-$ drawbar efficiency; $\mathrm{FC}_{\mathrm{S}}-$ specific fuel consumption; $\mathrm{ET}_{\eta}$ - engine thermal efficiency; $\mathrm{TP}$ - turbo pressure; $\mathrm{I}_{\mathrm{T}}$ - intake air temperature; $\mathrm{E}_{\mathrm{T}}$ - exhaust gas temperature; $\mathrm{T}$ - transmission factor; $\mathrm{v}_{\mathrm{T}}-$ target velocity factor; $380 \mathrm{CVT}$ - tractor with CVT transmission; 340 FPS - tractor with FPS transmission.

TABLE 3 shows that the tractor equipped with FPS transmission provided $9.05 \%$ more of the energy provided by the engine (i.e. $\mathrm{DB}_{\eta}$ ), even with less power. This parameter highlights the efficiency of this transmission system in relation to CVT, due to the greater capacity to transfer the available energy to the wheelsets. The efficiency of these transmission mechanisms is directly related to the energy demanded for its operation and the losses generated, considering that the CVT mechanism requires an auxiliary pump for its operation. Molari \& Sedoni (2008) point out that the factors gear speed, lubrication regime, transmission material and oil temperature directly influence power losses and, therefore, the efficiency.

The smallest $\mathrm{FH}_{\mathrm{C}}$ and the greatest capacity to transfer available energy $\left(\mathrm{DB}_{\eta}\right)$ of the $340 \mathrm{FPS}$, express the most efficient use of the fuel demanded, resulting in a lower specific fuel consumption. Also, the $380 \mathrm{CVT}$ required $58 \mathrm{~g}$ $(23.02 \%)$ more fuel to generate the energy equivalent to the $340 \mathrm{FPS}$, indicating less efficiency in converting fuel to work, as explained by Mayet et al. (2019). Furthermore, due to this lower $\mathrm{FC}_{\mathrm{S}}$, it can also be seen in TABLE 3 that the $380 \mathrm{CVT}$ presented $6.89 \%$ less in the use of energy in the engine (i.e. $E T_{\eta}$ ). The high energy efficiency of the 340 FPS compared to the 380 CVT demonstrates greater use of the calorific value of fossil fuels, an essential factor for the development of sustainable agriculture (Bietresato et al., 2015).

And finally, the highest exhaust gas temperature for the 340 FPS was provided by the highest expressed $E_{R}$, as reported and explained by Bietresato et al. (2015). In addition, this factor was also higher due to the higher air intake temperature observed in the engine, which was increased due to the variation in air temperature (i.e., uncontrollable factors), as well as the higher $\mathrm{DB}_{\mathrm{P}}$ and $\mathrm{DB}_{\eta}$ expressed, with greater power requirements for traction, which generated greater engine effort and, consequently, increased $\mathrm{E}_{\mathrm{T}}$ (Castellanelli et al., 2008).

Analyzing the isolated effect of $\mathrm{v}_{\mathrm{T}}$ on the second set of parameters evaluated, we observe the linear behaviour for $\mathrm{DB}_{\eta}$ and TP $\left(\mathrm{R}^{2}>0.96\right.$ - FIGURE 4a,d) and quadratic for $\mathrm{FC}_{\mathrm{S}}, \mathrm{ET}_{\eta}, \mathrm{I}_{\mathrm{T}}$ and $\mathrm{E}_{\mathrm{T}}\left(\mathrm{R}^{2}>0.88-\mathrm{FIGURE} 4 \mathrm{~b}, \mathrm{c}, \mathrm{e}, \mathrm{f}\right)$. 


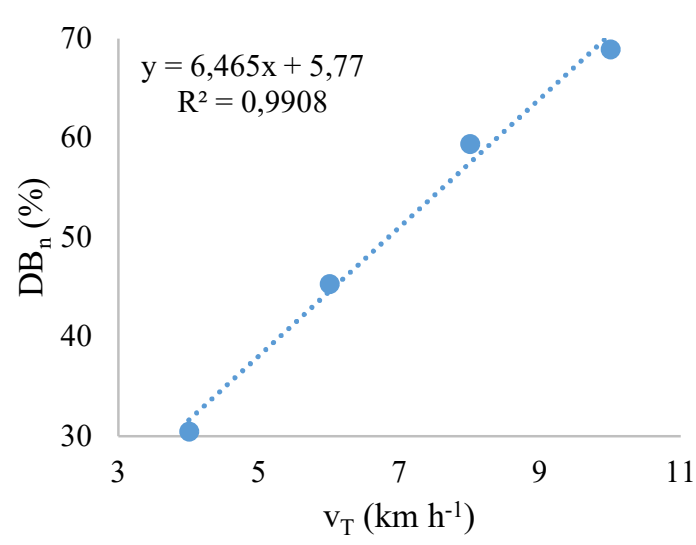

(a)

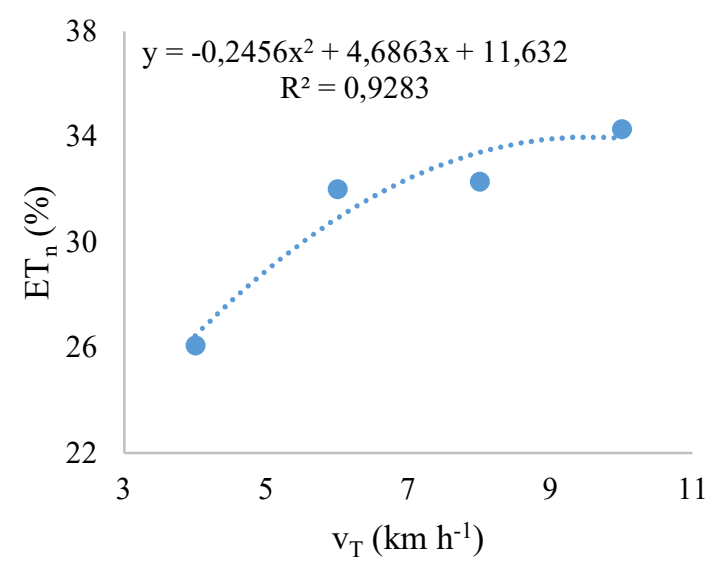

(c)

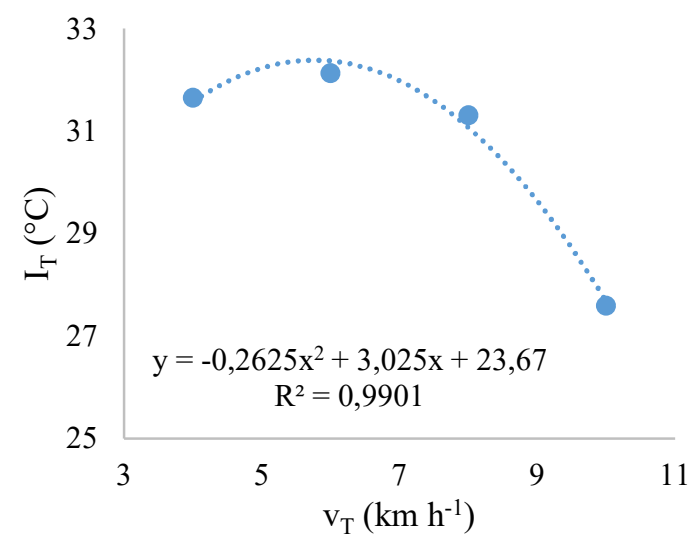

(e)

(e)

FIGURE 4. Regression analysis for the isolated target velocity $\left(\mathrm{v}_{\mathrm{T}}\right)$ factor in the parameters: (a) drawbar performance $\left(\mathrm{DB}_{\eta}\right)$; (b) specific fuel consumption $\left(\mathrm{FC}_{\mathrm{S}}\right)$; (c) engine thermal efficiency $\left(\mathrm{ET}_{\eta}\right)$; (d) turbo pressure (TP); (e) intake air temperature $\left(\mathrm{I}_{\mathrm{T}}\right)$; and, (f) exhaust gas temperature $\left(\mathrm{E}_{\mathrm{T}}\right)$.

FIGURE $4 \mathrm{a}$ shows an increase of $6.46 \%$ in the drawbar efficiency with an increase of $1 \mathrm{~km} \mathrm{~h}^{-1}$, added to $5.77 \%$ due to the travel velocity and the ratio weight-power of the tractor. According to Monteiro et al. (2013), this can be explained by $\mathrm{DB}_{\eta}$ varying according to the magnitude of the torque that the motor-transmission set is capable of applying to the wheelset. According to the equation generated in FIGURE $4 \mathrm{~b}$, the lowest $\mathrm{FC}_{\mathrm{S}}\left(256.86 \mathrm{~g} \mathrm{~kW} \mathrm{~h}^{-1}\right)$ occurred at $\mathrm{v}_{\mathrm{T}}=8.45 \mathrm{~km} \mathrm{~h}^{-1}$. Low values of specific fuel consumption in higher $\mathrm{v}_{\mathrm{T}}$ mean simultaneous optimization of engine performance, efficiency in traction and the suitability of the implement to the energy supply. Regarding

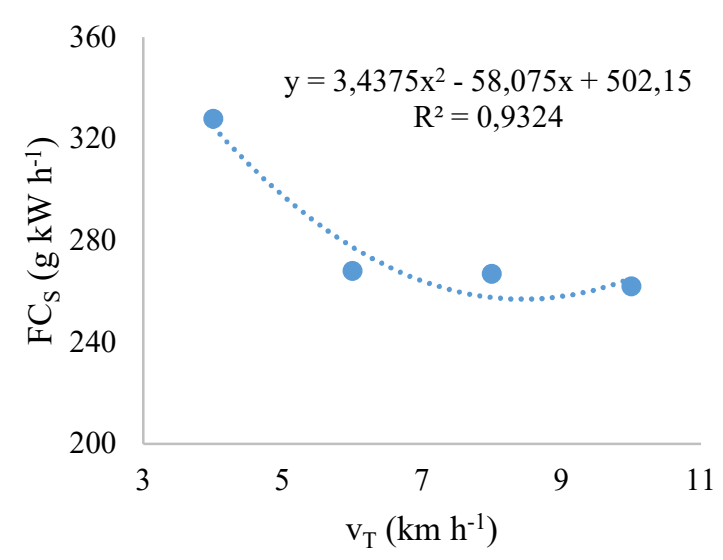

(b)

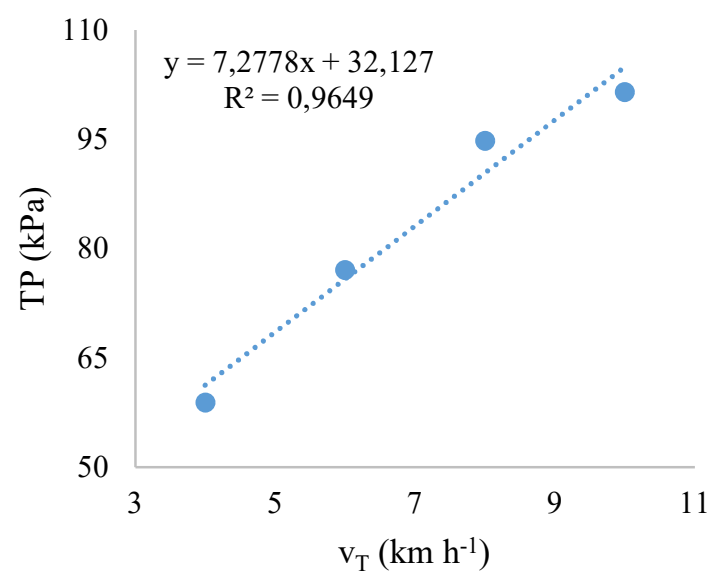

(d)

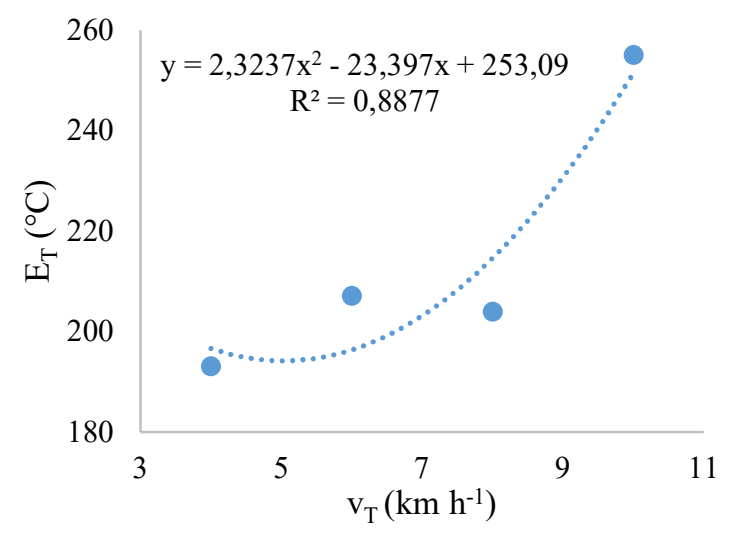


the fraction of the exhaust gases (Zhang et al., 2013). Furthermore, higher speeds require an increase in injected fuel, resulting in an increase in the enthalpy of the gases released in the exhaust (Giakoumis, 2016).

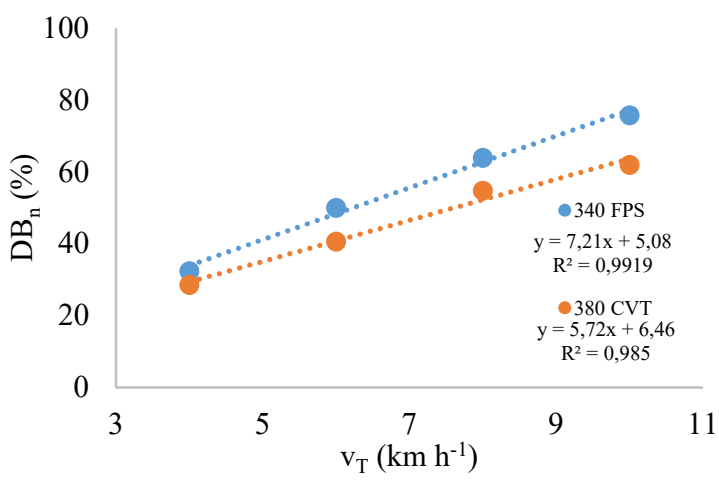

(a)

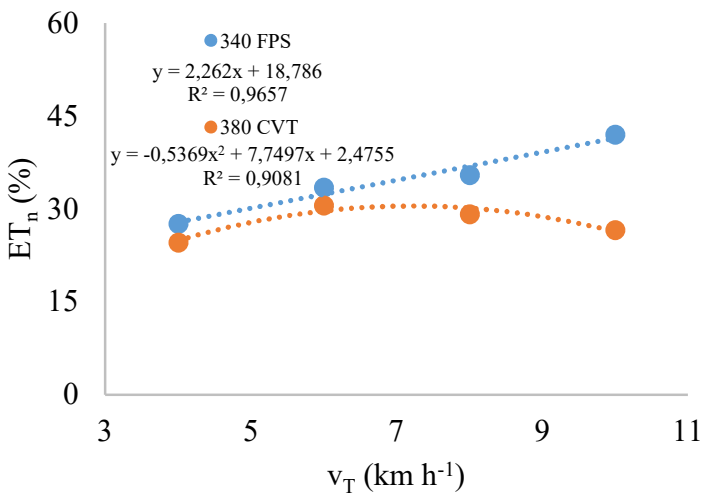

(c)

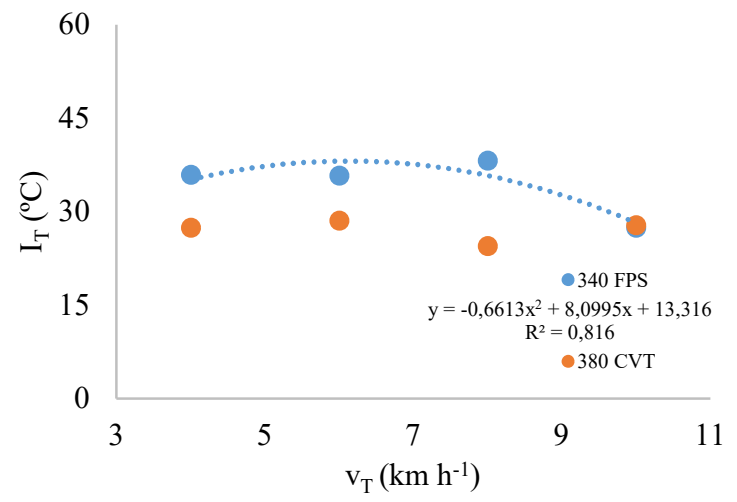

(e)

FIGURE 5. Regression analysis of the interaction transmissions (340 FPS and $380 \mathrm{CVT})$ and target velocity ( $\mathrm{v}_{\mathrm{T}}$ ) in the parameters: (a) drawbar efficiency $\left(\mathrm{DB}_{\eta}\right)$; (b) specific fuel consumption $\left(\mathrm{FC}_{\mathrm{S}}\right)$; (c) engine thermal efficiency $\left(\mathrm{ET}_{\eta}\right)$; $(\mathrm{d})$ turbo pressure (TP); (e) intake air temperature $\left(\mathrm{I}_{\mathrm{T}}\right)$; and, (f) exhaust gas temperature $\left(\mathrm{E}_{\mathrm{T}}\right)$.

The drawbar efficiency showed a positive linear trend with an increase in $\mathrm{v}_{\mathrm{T}}$ for both transmissions types $\left(\mathrm{R}^{2}>0.98\right.$ - FIGURE 5a). The 340 FPS had the highest $\mathrm{DB}_{\eta}$ in all $\mathrm{v}_{\mathrm{Ts}}$, which was increased by 1.31 times more with an increase in velocity by $1 \mathrm{~km} \mathrm{~h}^{-1}$, showing greater efficiency in transferring the energy provided by the engine to the wheelsets. On the other hand, the lowest $\mathrm{DB}_{\eta}$ observed on the 380 CVT can be attributed to the energy demand of the additional hydraulic pump for its operation.

With the increase in $\mathrm{v}_{\mathrm{T}}$, the $\mathrm{FC}_{\mathrm{S}}$ showed linear and quadratic trends for the $340 \mathrm{FPS}$ and $380 \mathrm{CVT}$, respectively $\left(\mathrm{R}^{2}>0.91-\right.$ FIGURE $\left.5 \mathrm{~b}\right)$. The tractor equipped with FPS transmission had lower $\mathrm{FC}_{\mathrm{S}}$, reducing $16.66 \mathrm{~g} \mathrm{~kW} \mathrm{~h}^{-1}$ with
As with the first set of parameters, equations were generated through the significant interactions shown in TABLE 3 between $\mathrm{v}_{\mathrm{T}}$ and the types of transmission (FIGURE 5).

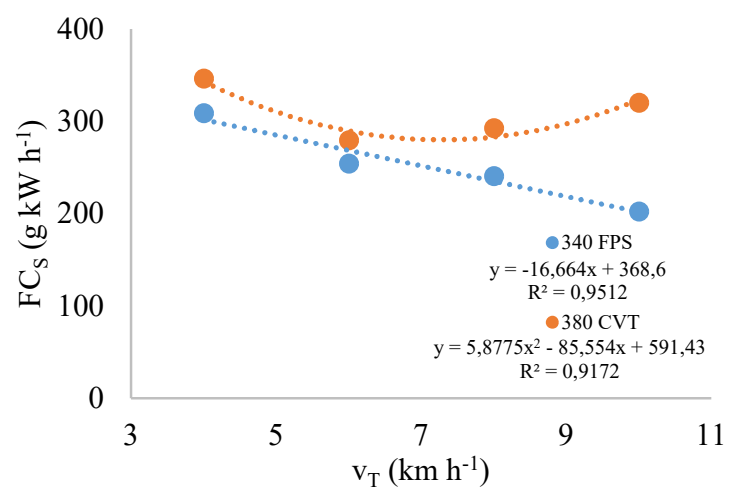

(b)

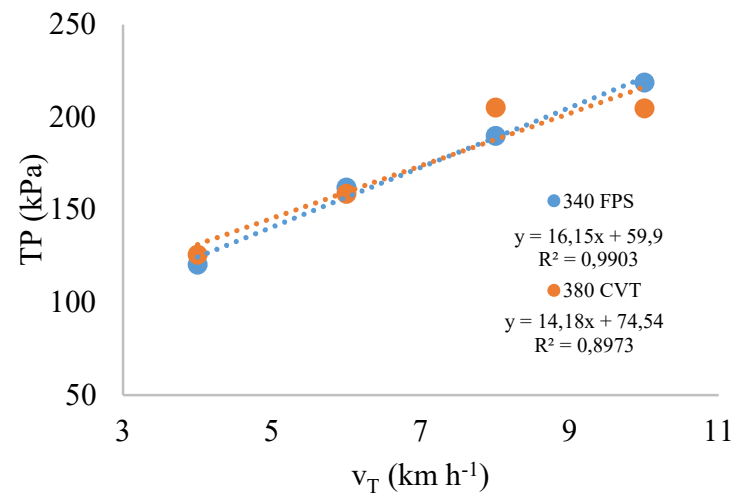

(d)

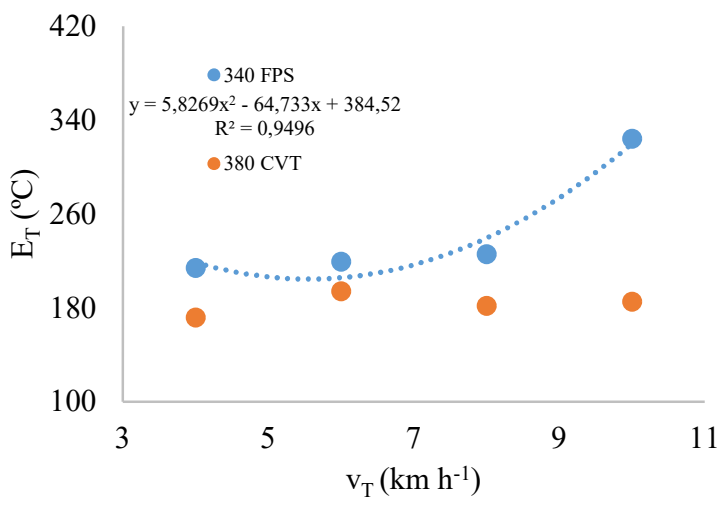

an increase of $1 \mathrm{~km} \mathrm{~h}^{-1}$, providing greater efficiency at higher target velocities. On the other hand, the $380 \mathrm{CVT}$ had the lowest $\mathrm{FC}_{\mathrm{S}}\left(280.09 \mathrm{~g} \mathrm{~kW} \mathrm{~h}^{-1}\right)$ at $\mathrm{v}_{\mathrm{T}}=7.27 \mathrm{~km} \mathrm{~h}^{-1}$. Therefore, since the 340 FPS requires less fuel to produce the same energy, a higher $\mathrm{ET}_{\eta}$ is observed compared to the 380 CVT, which is higher in all evaluated $\mathrm{v}_{\mathrm{T}}$ (FIGURE 5c). This greater efficiency of use is evidenced mainly at the highest $\mathrm{v}_{\mathrm{T}}$, due to the $380 \mathrm{CVT}$ tractor having a maximum $\operatorname{ET}_{\eta}(28.27 \%)$ at $\mathrm{v}_{\mathrm{T}}=5.21 \mathrm{~km} \mathrm{~h}^{-1}$, which is $2.29 \%$ lower than the 340 FPS. The behaviour of this parameter on the 340 FPS tractor showed a linear trend with an increase of 2.26 times with an increase of $1 \mathrm{~km} \mathrm{~h}^{-1}$ as well. 
The linear increase in the turbo pressure shown in FIGURE 5d, for both transmission systems, showed an average variation of $9.55 \mathrm{kPa}$ between them, due to the need to increase the supply of air volume to meet the ratio between air and fuel on the engine cylinders. The adjustment of the pressure and volume of compressed air is provided by changing the geometry of the turbine rotor vanes, which takes into account the engine speed and load condition (Feneley et al., 2017; Giakoumis \& Tziolas, 2018).

The engine's air intake temperature at $\mathrm{v}_{\mathrm{T}}$ of 4,6 and $8 \mathrm{~km} \mathrm{~h}^{-1}$ was, on average, $9.82{ }^{\circ} \mathrm{C}$ lower for the $380 \mathrm{CVT}$ factor, and similar at $\mathrm{v}_{\mathrm{T}}=10 \mathrm{~km} \mathrm{~h}^{-1}$ compared to the $340 \mathrm{FPS}$ (FIGURE 5e). As previously mentioned, this can be explained by the variation of the air temperature in the environment during the course of the experiment, since the temperature was collected at the entrance of the air filter in both cases.

Analyzing FIGURE 5f, the 340 FPS showed a higher exhaust gas temperature at all $\mathrm{v}_{\mathrm{T}}$ compared to the $380 \mathrm{CVT}$, which can be explained by the higher $E_{R}$ and torque obtained by the 340 FPS, plus the higher air intake temperature of the motor, as previously shown in FIGURE 5e (Bietresato et al., 2015). According to Macor \& Rossetti (2011), the energy expenditure observed in the 380 CVT tractor, in relation to the $340 \mathrm{FPS}$, is due to the double energy conversion that occurred in the transmission's hydraulic branch. However, tractors equipped with hydromechanical transmissions provide part of the power through a mechanical path, which is considered more efficient, and partly by a CVT, therefore conditioning greater durability of the components due to the smoothing of gear changes.

\section{CONCLUSIONS}

The tractor with FPS transmission was more energy efficient in most of the analyzed parameters, requiring less in hourly fuel consumption, and providing more in the traction bar yield, however, with lower operational velocity in relation to the tractor with CVT transmission.

\section{REFERENCES}

ASAE - American Society for Agricultural Engineering (2011a) Agricultural machinery management data. EP496.3. In: ASAE Standards: Standards engineering practices data. St. Joseph, American Society of Agricultural Engineers.

ASAE - American Society for Agricultural Engineering (2011b) Agricultural machinery management data. EP497.7. In: ASAE Standards: Standards engineering practices data. St. Joseph, American Society of Agricultural Engineers.

Battiato A, Diserens E (2017) Tractor traction performance simulation on differently textured soils and validation: A basic study to make traction and energy requirements accessible to the practice. Soil and Tillage Research 166:18-32.

Bietresato M, Calcante A, Mazzetto F (2015) A neural network approach for indirectly estimating farm tractors engine performances. Fuel 143:144-154.
Bietresato M, Friso D, Sartori L (2012) Assessment of the efficiency of tractor transmissions using acceleration tests. Biosystems Engineering 112 (3):171-180.

Castellanelli M, Souza SNM, Silva SL, Kailer EK (2008)

Desempenho de motor ciclo diesel em bancada dinamométrica utilizando misturas diesel/biodiesel. Engenharia Agrícola 28 (1):145-153.

Damanauskas V, Janulevičius A (2015) Differences in tractor performance parameters between single-wheel 4WD and dual-wheel 2WD driving systems. Journal of Terramechanics 60:63-73.

Damanauskas V, Velykis A, Satkus A (2019) Efficiency of disc harrow adjustment for stubble tillage quality and fuel consumption. Soil and Tillage Research 194:104311.

Farias MS, Schlosser JF, Linares P, Barbieri JP, Negri GM, Oliveira LFV, Rüdel IYP (2017) Fuel consumption efficiency of an agricultural tractor equipped with continuously variable transmission. Ciência Rural 47 (6):1-7.

Feneley AJ, Pesiridis A, Andwari AM (2017) Variable geometry turbocharger technologies for exhaust energy recovery and boosting. Renewable and Sustainable Energy Reviews 71:959-975.

Ferreira PV (2018) Estatística experimental aplicada as ciências agrarias, Viçosa, Editora UFV. 588p.

Gabriel Filho A, Lanças KP, Leite F, Acosta JJB, Jesuino PR (2010) Desempenho de trator agrícola em três superfícies de solo e quatro velocidades de deslocamento. Revista Brasileira de Engenharia Agrícola e Ambiental 14 (3):333-339.

Giakoumis EG (2016) Review of some methods for improving transient response in automotive diesel engines through various turbocharging configurations. Frontiers in Mechanical Engineering 2:1-18.

Giakoumis EG, Tziolas V (2018) Modeling a variablegeometry turbocharged diesel engine under steady-state and transient conditions. Journal of Energy Engineering 144 (3):04018017.

Jasper SP, Bueno LSR, Laskoski M, Langhinotti CW, Parize GL (2016) Desempenho do trator de $157 \mathrm{~kW}$ na condição manual e automático de gerenciamento de marchas. Revista Scientia Agraria 17 (3): 55-60.

Li B, Sun D, Hu M, Zhou X, Liu J, Wang D (2019) Coordinated control of gear shifting process with multiple clutches for power-shift transmission. Mechanism and Machine Theory 140: 274-291.

Lopes A, Câmara FTD, Scala Jr N, Furlani CE, da Silva RP, Barbosa AL (2010) Desempenho operacional de um protótipo "aerossolo". Engenharia Agrícola 30 (1):82-91.

Macor A, Rossetti A (2011) Optimization of hydromechanical power split transmissions. Mechanism and Machine Theory 46 (12):1901-1919.

Martins MB, Sandi J, Souza F, Santos, RS, Lanças KP (2018) Otimização energética de um trator agrícola utilizando normas técnicas em operações de gradagem. Revista Engenharia na Agricultura 26 (1):52-57. 
Mattetti M, Maraldi M, Sedoni E, Molari G (2019) Optimal criteria for durability test of stepped transmissions of agricultural tractors. Biosystems Engineering 178:145-155.

Mayet C, Welles J, Bouscayrol A, Hofman T, LemaireSemail B (2019) Influence of a CVT on the fuel consumption of a parallel medium-duty electric hybrid truck. Mathematics and Computers in Simulation 158:120-129.

Molari G, Sedoni E (2008) Experimental evaluation of power losses in a power-shift agricultural tractor transmission. Biosystems Engineering 100 (2):177-183.

Monteiro LA, Albiero D, Souza FH, Melo R, Cordeiro IM (2013) Tractor drawbar efficiency at different weight and power ratios. Revista Ciência Agronômica 44 (1):70-75.

Monteiro LA, Lanças KP, Guerra SPS (2011)

Desempenho de um trator agrícola equipado com pneus radiais e diagonais com três níveis de lastros líquidos. Engenharia Agrícola 31 (3):551-560.

Oiole YA, Kmiecik LL, Parize GL, Silva TXD, Jasper SP (2019) Energy Performance In Disc Harrowing Operation In Different Gradients And Gauges. Engenharia Agrícola 39 (6):769-775.

Park YJ, Kim SC, Kim JG (2016) Analysis and verification of power transmission characteristics of the hydromechanical transmission for agricultural tractors. Journal of Mechanical Science and Technology 30 (11): 5063-5072.

Piros A, Farkas Z (2012) Fuzzy-based evaluation of a specific drive train. Advances in Mechanical Engineering 4:763171.
Qu D, Luo W, Liu Y, Fu B, Zhou, Zhang, F (2019) Simulation and experimental study on the pump efficiency improvement of continuously variable transmission. Mechanism and Machine Theory 131:137-151.

Rotella D, Cammalleri M (2018) Power losses in powersplit CVTs: A fast black-box approximate method. Mechanism and Machine Theory 128:528-543.

Serrano JM, Peça JO, da Silva JM, Pinheiro A, Carvalho M (2007) Tractor energy requirements in disc harrow systems. Biosystems Engineering 98 (3):286-296.

Simikic M, Dedovic N, Savin L, Tomic M, Ponjican O (2014) Power delivery efficiency of a wheeled tractor at oblique drawbar force. Soil and Tillage Research 141:32-43.

Strapasson L, Kmiecik LL, Jasper SP, Zimmermann GG, Savi D (2020) Interference of the number of remote control valves in use on the energy performance of an agricultural tractor with productivity management. Engenharia Agricola 4 (3):356-362.

Vantsevich VV (2007) Multi-wheel drive vehicle energy/fuel efficiency and traction performance: Objective function analysis. Journal of Terramechanics 44 (3):239-253.

Xia Y, Sun D, Qin D, Zhou X (2020) Optimisation of the power-cycle hydro-mechanical parameters in a continuously variable transmission designed for agricultural tractors. Biosystems Engineering 193: 12-24.

Zhang Q, Pennycott A, Brace CJ (2013) A review of parallel and series turbocharging for the diesel engine. Journal of Automobile Engineering 227 (12):1723-1733. 